\title{
Managerial Innovation in the Public Sector: An Exploratory Study on the State University Administration in Sri Lanka
}

\author{
R. L. S. Fernando \\ University of Sri Jayewardenepura, Sri Lanka
}

\begin{abstract}
Universities are expected to provide employable and quality graduates. The government of Sri Lanka provides education facilities to the nations and the total expenditure incurred from the General Treasury. However, a lack of financial resources is one of main constraints being faced by the State universities. These situations negatively affect the performance of the students. Even though, the financial and other constraints remain, universities would not reduce the expected service delivery. Thus, this paper argues that universities could perform in innovative ways in managing their educational programmes that would lead to improve the quality and the relevance of the output of the universities leading to more effective and efficient administration. Thus, this study examines the utility of innovation theory in university administration in Sri Lanka. The study attempts to answer two main research questions: Is innovation possible in the university Administration? And what are the main factors affecting on innovation in the university administration? Qualitative research approach with a purposive sample of 20 administrators from four universities from the Western Province was selected by using reputed snowballing technique. Descriptive analysis was undertaken. The study confirmed that innovation is possible and already happening within the university administration. Innovation in university administration means introducing and implementing systems of management by using new ideas to improve the
\end{abstract}

\section{Corresponding Author:}

R.L.S. Fernando is a Professor at the Department of Public Administration, University of Sri Jayewardenepura, Nugegoda, Sri Lanka. E-mail: rlsf@sjp.ac.lk 
efficiency and the effectiveness of the degree programs. The study presents several innovative practices initiated by the university administration which have created potential benefits to the degree programs. The administrators' motivation to achieve is the significant determinant of the managerial innovation and supportive environment which is mainly the supports of the academic staff and the external environment are other significant determinants of managerial innovation in the administration of the selected universities in Sri Lanka.

\section{Keywords}

Managerial Innovation, Public Sector, University Administration

\section{Introduction}

With the rapid development of information technology, globalization and international competitiveness in the world economy, management scholars and practitioners have paid more interest on innovation in the last few decades. "Interest in innovation in the public sector has also grown substantially in the last 15 years" (Borins, 2001). "Managerial innovation" is not a new concept in the field of public management, though a few researchers have paid attention to this topic in Sri Lanka. Improving performance of the public service is the key challenge faced by managers in the public sector organizations. Fernando $(2004 ; 2006)$ argued that, in order to respond to the peoples' demands under the conditions of limited resources, there is a need to change the role and the behavior of the managers in the public sector. Further, the above research emphasizes that it was necessary for public managers to perform in innovative ways in supplying goods and services as it enhanced the ability to perform administrative and managerial activities in a different way leading to more efficient and effective public services.

Similar to other public organizations, universities in any country are committed to play a vital role in creating and dissemination of knowledge through teaching, research while actively contributing to the national development in various ways. Further, those universities are supposed to produce quality graduates to suit the job market that would directly contribute to economic development. However, public universities in Sri 
Lanka are getting limited financial resources from the Treasury due to the continued budget deficit of the government within the last few decades. The expenditure on education has been gradually reduced for the last several years (i.e. the government allocated only 2.59 percent, 2.67percent, 2.59percentand 2.27percent of GDP for the years of 2005, 2006, 2007 and 2008 respectively). One of the Heads of the Department, in the biological field of a State university in Sri Lanka acknowledged at a meeting that the government did not allocate additional funds to that particular Faculty for the last few years (field data, 2010). Under this situation, administrators face various difficulties especially in conducting practical sessions where more expensive instruments are needed especially, in the Science and Medical fields. In most of the other faculties, the situation seems to be the same. The same head of the department mentioned above has declared that the respective faculty has taken alternative ways to find the required resources for a better implementation of their scheduled educational programs. Thus, this study argues that, despite these constraints, innovative behavior of the university administration seems to have a potential avenue to improve service delivery in efficient and effective ways. Many researchers (Liyanage, 2014; Tharmaseelan, 2007) and practitioners (Warnapala, 2007; Samaranayake, 2013) in Sri Lanka also emphasize the necessity of a change in the university system in Sri Lanka. This research would be the initial work in the field of managerial innovation in the public sector especially, related to the higher education institutions in the state sector in Sri Lanka. Thus, this study intends to fill a gap of knowledge on innovative behaviors in the state university administration in Sri Lanka. It is also expected that the administrators in the higher educational sector will be able to learn lessons from the innovative managerial practices initiated by the selected sample in this study. Thus, the findings of this research would contribute to create new knowledge in the field of public management in general and also it would help to find guidelines in improving performance of the state universities particularly in Sri Lankan context. The aim of this study is to identify the key determinants of innovative behavior of the university administrators/managers in Sri Lanka.

The rest of the paper begins with a review of theoretical background of the managerial innovation in general and then specifically the managerial innovation in relation to the public sector. Secondly, the research 
methodology of this study is discussed and the results of the research are reported. Finally, the implications for improving innovative behavior of the university administrators are explained.

\section{Literature Review}

\section{Managerial Innovation}

Innovation is not a familiar concept in the field of public management. However, the term does not mean large scale invention. Simply, it can be defined as a change or looking at something in a new way or doing something in a different way. The Oxford English Dictionary defines innovation as the introduction of a new thing, and the alteration of something established. Shukla (2009) defines innovation as exploiting new ideas leading to the creation of a new product, process or service. The term Managerial Innovation is defined as "Generation, acceptance and implementation of new ideas, process, and products or services" (Thompson, 1965). Here, Thompson identifies managerial innovation as not only in generating and implementing of new ideas, but also accepting someone's new ideas as well. Similar to this definition, Yin (1977) defines organizational innovation as originating predominantly from the motive of improving goods and services provided by the organization. Various types of innovation have been identified and defined by several researchers. According to Public Report No.20 (2005) it is possible to divide the innovation in the public sector into many types such as; new or improved service (e.g. health care), process innovation (e.g. change in the manufacturing of a service or product), administrative innovation (e.g. a new policy instrument), system innovation (e.g. a fundamental change of an existing system), conceptual change (e.g. introducing new concept), radical change of rationality (e.g. changing the world view).

Stone (1981) explains that the government innovations take many forms. "They apply to objectives and policies, character of product or services, hardware and software technology, procedure and process. They are also involved in the structure, management style and systems, including and external relationships" (Stone, 1981, p. 508). Mohamed (2002) has provided descriptions of five types of innovations namely, the service innovation (the introduction of new services to meet client needs, whether these clients are internal or external), the process innovation (making 
adjustments to the workflow in the department), the administrative innovation (refers to structural adjustments made in order to deal with the changes and to facilitate the provision of efficient and effective services to clients), the operational innovation (describes new methods, styles and equipment used to change or improve the way the department does it business) and finally, the system innovation (related to new elements introduced to organize the work of group member themselves, such as the performance appraisal, the incentive systems, the resource allocation, and so on).

\section{The necessity of innovation in public sector}

There has been substantial research (Leavy, 2010; Mole \& Worrall, 2001; Georgellis, Joyce, \& Woods, 2000) in relation to innovation in the business sector. The interest in innovation in the public sector has also grown substantially in the last fifteen years (Borins, 2001). One of the tenets of the New Public Management (NPM) is the adoption of managerial innovations and namely private sector management practices into the public sector. As a result the efficiency and the effectiveness of the public sector organizational performance also can be enhanced (Hood, 1991; Dixon et al., 1988; Flury \& Schedler, 2006; Ryan et al., 2008 cited in Arnaboldi, Azzone\& Palermo, 2010, p. 81). Studies have confirmed that all businesses want to be more innovative and believe that innovation is a priority for them. According to Drucker (1994) the only way a business can hope to prosper, if not to survive, is to innovate. It is the only way to convert change into opportunities. Today markets are highly competitive and dynamic, managers especially, in the private sector concern on strategic planning to become successful. Thus, Lyonnais and Houle-Rutherford (1996) has mentioned innovativeness as a major factor in influencing strategic planning. Even though efficiency was essential for business success, in the long run, it could not sustain business growth. Innovation leaded to wealth creation. Many organizations, especially in the private sector, are now adopting measures to strengthen their ability to innovate. In addition to that several researches (Goedhuys, 2007; Mansury \& Love, 2008; Lopez, 2009) have indicated that innovation has a significant impact on productivity and growth. Therefore, innovators are more needed than ever before. Lyonnais and Houle-Rutherford (1996) emphasize that innovation will bring added value and widen the employment base. Further, these authors emphasize 
that innovation will make the world a better place for the younger generation. Thus, the concept of managerial innovation has been received a significant attention.

Drucker (1994) emphasizes the importance of innovation in the public sector for the success in their organizations. "Public service institutions such as government agencies, labor unions, churches, universities, schools, hospitals, community and charitable organizations, professional and trade associations and the like need to be entrepreneurial and innovative fully as much as any business does, indeed they may need more" (Drucker, 1994, p.162).There is also growing evidence that substantial increases in productivity can be made in public sector organizations through innovative management techniques, procedures, and hardware products (Rossenger, 1977 cited in Fernando, 2006, p.225). Vigoda-Gadot, Shoham, Schwabsky and Ruvio (2008) stated that innovation in the public sector is a powerful engine and a key instrument for the reform and revitalization of both fully state owned bodies and quasi-governmental organizations. As in the above discussions, public service innovations are replicated by private sector in order to enhance the overall efficiency. Public managers will have to be innovative and develop innovative ways of supplying goods and services because innovation enhances the ability to perform administrative activities in a different way (Fernando, 2006). By presenting several innovative practices related to the Sri Lanka Administrative service, Fernando (2006) acknowledges that managerial innovations lead to a change in the existing working patterns, systems, procedures, styles leading to more efficiency and effectiveness in the delivery of public service. Further, Fernando (2006) notes that managerial innovation helps to reduce the cost, generate the income and increase the peoples' satisfaction towards the public service.

\section{Managerial Innovation in the Public Sector}

Public sector services include all organizations and activities financed out of public revenue, and the services provided by government. The importance of innovative managers for the innovative public sector organizations has been highlighted by Stone (1981). Stone argues that innovative organizations require innovative managers. Therefore he further emphasizes that the appointment and development of innovative executives/managers will strengthen any organization, only when they have developed an 
innovative and participatory workforce. Then organizational innovation with tangible benefits begins to appear. Further, the author acknowledges that, in order to become innovative, a city, country, state or national agency requires strengthening of elements contributing to administrative capability such as suitable legal structure, a responsible well-functioning legislative body, competent executive and management leadership, facultative administrative organization, effective managerial and supportive process, adequate budgetary resources, a high quality workforce, and a supportive political environment. Another study related to a government organization done by Mohamed (2002) reveals that the managerial attitude, the decentralization, the supervisory support, the group satisfaction, the diversity and committee membership are significant predictors of group innovation. Awamleh (1994) also examines the relationship between the managerial innovation as dependent variable and sex, age, education, organizational level and length of services as independent variables and finds that there is a negative yet weak relationship between innovation and age, organizational level, and length of service and there is a positive yet weak relationship between innovation and education and sex. Further this research finds that the most significant obstacles to innovation are the organizational climate. Arnaboldi et al. (2010) explores the adoption of managerial innovation in the public sector with reference to two case studies in the Italian Central Government institution. Both cases represent a failure in adoption and the use of managerial innovation attributable to a complex interplay of external and organizational forces. Further, Arnaboldiet al. (2010) finds that the failure of both projects is due to key individuals' inability: first to "make sense" of what the innovation is about and second, to communicate this "sense" throughout the organization. Thompson (1965) examines the relationship between bureaucratic structure and innovative behavior and suggests alterations in bureaucratic structure to increase innovativeness, such as increased professionalism, a looser and more untidy structure, decentralization, freer communications, project organization when possible, rotation of assignments, greater reliance on group processes, attempts at restructuring, modifications of the incentive system, and changes in many management practices. Factors shown to have affected the diffusion of innovations in prior work include the external context, organizational characteristics and diffusion drivers (Walker, 2006). Yin (1977) hypothesizes the external environment of innovative agency, the agency 
itself, the desired characteristics of the innovative devices and the specific innovative efforts which are attributed to increase the probability of organizational change.

A study by Mohr (1969) also finds that the innovation in public agencies is the function of an interaction among the motivation to innovate, the strength of obstacles against innovation, and the availability of resources for overcoming such obstacles. According to Stone (1981) innovative and productive organizations (public and private organizations) cannot be created and maintained without executives and managers who possess the knowledge and competencies in handling the tasks, processes and relationships inherent in executive/managerial responsibilities, and also intellectual, entrepreneurial behavioral interpersonal abilities and traits characteristics of successful executives/managers and substantive, technological and other contextual knowledge and skills in fields or jurisdiction in which the executive/managerial role is carried out. Mohamed (2002) examines the link between a set of organizational and group variables and the level of innovation in relation to a sample from 150 government divisions in the United Arab Emirates and the results indicates that managerial attitude, decentralization, supervisory support, group satisfaction, diversity, committee membership, and management learning are significant predictors of group innovation.

Dewett, Whittier and Williams (2007) provide a framework for understanding post adoption innovation implementation and finds that the organizational, innovation and human influences represent unique challenges for innovation implementation. Vigoda-Gadotet et al. (2008) examines a model of public sector innovation across a multinational sample of eight countries and 626 participants. This research develops a theory of antecedents and consequences of innovation in public administration as perceived by knowledgeable citizens and end users. Major findings of this research indicate that responsiveness together with leadership and vision are important antecedent of innovation in the public sector, public sector innovation affects trust in and satisfaction with public organization, and the effect of public sector innovation on trust and satisfaction is both direct and mediated by the image of public organization. Borins (2001) identifies conditions that lead to public management innovation. These conditions are 
initiatives coming from the political system, the new leadership, a crisis (a current or anticipated publicly visible failure or problem, the internal problems (such as inability to reach target population, the inability to meet the target demand for a program, the resource constraints, or an inability to coordinate policies) and the new opportunities, created either by technological or other factors. In relation to the Sri Lankan organizations, Ranasinghe (2002) conceptualizes the problem of lack of innovation in terms of the conceptual model, which recognizes strategic leadership and achievement culture as critical variable of organizational learning and innovation.

\section{Methodology}

\section{Research Design}

This study applied qualitative method to investigate the key determinants of innovative behavior of the university administrators/managers in Sri Lanka. The sample comprises with university administrators who have initiated innovative ideas in management including deans of the faculties, heads of departments and coordinators of academic programmes of State universities. For the qualitative data collection, 20 in-depth interviews were conducted based on a snowballing sample. The interviews were conducted during the period of March 2009 to June 2009. The sample was confined only to four State universities located in the Western Province for the convenience of the researcher. Initially, five respondents were selected from the University of Sri Jayewardenepura based on the researcher's understanding of the concept according to the literature. Thereafter, the other respondents were selected based on the ideas given by senior academics and administrators in the respective universities. A content analysis and a thematic analysis were employed to analyze data.

\section{Data Analysis and Discussion}

\section{Demographic Characteristics of the Sample}

The selected twenty administrators comprised with fifteen (15) male and five female. Among them two (02) were Deans and seventeen (17) of them were Heads of Departments and one coordinator (01) were included. Among them, ten (10) administrators were from the Faculty of Management Studies and Commerce and four (04) were from the Faculty of Engineering and 
other four (04) were from the Faculty of Arts and Humanities. Only two (02) administrators were from the Faculty of Physical Sciences. Among the respondents, only three (03) were Professors and twelve (12) were in Senior Lecturer Grade I. Rest of the sample were in Senior Lecturer Grade II. Among the selected respondents, sixteen (16) administrators were Ph.D. holders. The minimum age of the sample was forty one (41) years and the maximum age was fifty seven (57) years. The demographic characteristics of the sample are given in Table 1.

Table 1: Demographic characteristics of the sample

\begin{tabular}{|c|c|c|c|c|c|c|}
\hline & Position & University & Faculty & $\begin{array}{c}\text { Age } \\
\text { (Yrs) }\end{array}$ & Gender & Qualification \\
\hline 01 & Head & SJP & App. Sci. & 45 & Male & MSc./SL Grade. I \\
\hline 02 & Head & SJP & Mgt. Stu & 46 & Male & PhD. / Prof. \\
\hline 03 & Head & Kelaniya & Social Sci. & 56 & Male & SL Grade 1/ PhD. \\
\hline 04 & Coordinator & SJP & Mgt. Stu & 43 & Male & PhD./SL Gra. I \\
\hline 05 & Head & Kelaniya & Science & 46 & Female & PhD./Prof. \\
\hline 06 & Head & Kelaniya & Mgt. Stu & 42 & Male & M.Com/SL Gra. I \\
\hline 07 & Head & Kelaniya & Mgt. Stu & 50 & Female & SL Grade 1/PhD. \\
\hline 08 & Head & Kelaniya & Humanities & 45 & Male & PhD./SL.Gra I \\
\hline 09 & Head & SJP & Mgt. & 44 & Female & MSc./SL Grade I \\
\hline 10 & Head & Colombo & Arts & 56 & Male & PhD./ Snr. Prof. \\
\hline 11 & Head & Colombo & Mgt. Stu & 45 & Male & PhD./SL. Gra II \\
\hline 12 & Head & Colombo & Arts & 57 & Male & PhD./ Prof. \\
\hline 13 & Head & Colombo & Mgt. Stu & 43 & Female & PhD./SL.Gra I \\
\hline 14 & Dean & Kelaniya & Mgt. Stu & 47 & Male & MBA/SL Gra. I \\
\hline 15 & Head & Moratuwa & Eng. & 41 & Female & PhD./SL. Gra. II \\
\hline 16 & Head & Moratuwa & Eng. & 48 & Male & PhD./ SL. Gra. I \\
\hline 17 & Head & Moratuwa & Eng. & 41 & Male & PhD./ SL. II \\
\hline 18 & Head & Moratuwa & Eng. & 43 & Male & PhD./ SL. Gra. I \\
\hline 19 & Dean & Colombo & Mgt. Stu & 52 & Male & PhD./SL.. Gra. I \\
\hline 20 & Head & Open & Mgt. Stu & 46 & Male & PhD./ SL. Gra. I \\
\hline
\end{tabular}

Source: Field Data

Note:SJP $=$ Sri Jayewardenepura, Mgt. Stu. $=$ Management Studies, Eng. $=$ Engineering, App. Sci. $=$ Applied Sciences, Social Sci. $=$ Social Sciences, Snr. Prof. $=$ Senior Professor

\section{Innovation in University Administration}

Most of the respondents confirmed that universities are conducive to innovation. Moreover, they said that there is no difference between managerial innovation among universities and elsewhere. In defining "innovation in university administration", a respondent said that it is "novel 
ways and means to manage the resources in an effective and efficient manner to improve the quality of the graduates". Another respondent's idea was that innovation is "introducing and implementing systems of management by using new ideas for improving efficient and effective degree programs/departments or the faculties". "Administrator must have a vision to change the existing activities and practices for improving the quality of the academic programs" is different perception held by some other respondent. Another idea derived from the study is "managerial innovation in the university administration is to improve the quality of the graduates including their values to achieve sustainable development of the society".

\section{Innovative Practices initiated by the Sample}

The content analysis of this study found that there are several common activities which university administrators have initiated as innovations. Prominently, new subjects have been introduced to improve students' soft skills which had not included to the previous curriculum. These subjects are expected to enhance students' communication skills, presentation skills, team spirit and language skills. Another innovative activity is the introduction of a new centre called "Statistical Case Studies" to learn and undertake various projects with the aim of improving analytical skills and interpretative skills of the students who are not specialized in statistics. Further, the study explored that a new component is added to evaluate students' competencies such as communication and presentation skills in addition to each course evaluation. Accordingly, evaluation criteria of all subjects in the course curriculum were changed in order to assess students' competencies. Another activity implemented as an administrative innovation imperative is the introduction of self-finance programmes to generate extra income for the university and also improve the human resources of the country by disseminating knowledge for the community even outside the university. Another university has introduced a new unit called "Knowledge Center" where the students and the teaching faculty could get benefits in various ways in terms of their research, teaching and learning. Establishment of a system to enhance the relationship between the industry and the University department in order to find internship and job opportunities for their undergraduates is also one of the innovations done by the selected university administrators in Sri Lanka. 
According to the view of the respondents most of these innovations have not required any financial resources. However, they have brought various advantages to the students, lecturers and the university and these practices are new and could not be considered as routine activities. Thus, the main purpose of all these innovation in university administration is to improve the quality and the relevance of the academic programmes. Based on the field data, the following factors were identified as major determinants of innovation in the State University administration.

\section{Determinants of Innovation in the State University Administration} Administrators' need to achieve

Most of the respondents accept that universities are good places for initiating changes, where they could initiate different ideas that benefits for their departments and the students. "I need to do something to my country as we are products of free education" (a respondent: field data). Some others' motive is to solve students' problems by introducing and implementing different activities and ideas. Some prefer to introduce new activities for their self-satisfaction. Several respondents said that various activities have been introduced for improving students' skills and building positive attitudes. "I have a confidence and a need to do something to my country as I received much from the free education in Sri Lanka: by doing that I can get more self-satisfaction" (a respondent: field data).

\section{Supportive environment specially the support from the academic staff}

The idea of the majority of the sample is that, if academics are supportive enough, new activities could be introduced and implemented without any difficulties. "New activities and innovative behavior could be done with the support of the department. Cooperation among the staff is very important to introduce new ideas and changes" (a respondent: field data). Several respondents said that, the support of the junior academics could be obtained without any difficulties than others. "Majority of the staff is hardworking and very supportive, that situation encourages me to initiate various activities and new ideas to the department" (a respondent: field data). Some other respondents confirmed that, if the higher authorities (eg. Vice chancellor has good understanding about the administration and 
administrative officers) are supportive, that will encourage them to initiate and implement innovative activities.

\section{Support of the external environment}

The study also revealed that there are some other factors which influence administrators to initiate innovative activities in the universities. These supportive factors can basically fall into financial and physical. Some departments offer various facilities and services which are different from the normal activities with the support of various public and private sector organizations. "We received a special donation from a foreign country as we have maintained a good relationship with them. Our students and academics benefit from these new facilities" (a respondent: field data). However, the same respondent stated that before getting the support of the external organizations, a prior approval is needed.

\section{Skills of human resources}

Several discussions revealed that the necessity of having committed, trained and skillful non-academic staff is required to have innovations in the universities.

\section{Policy Implications and Conclusion}

The findings of this research suggest that most of the university administrators take efforts to introduce innovative activities. This is due to the fact that the administrators are inspired by 'need to achieve'. They have the expectations on improving the quality of academic programmes, improving skills of the students, improving the employability of graduates and offering solutions to students' problems. Even though the state universities' administrators receive relatively a lower level of remuneration when compared to the private sector in Sri Lanka, the administrators dedicate to their work by introducing innovative ideas, concepts and programs in order to improve their academic programs. The possible reason behind this situation seems to be their positive attitudes and desire to do something to their organizations and the country. According to Fernando (2005) public entrepreneurs need to serve the country to solve the problems of the country. As the concept of entrepreneurship consists of mainly three dimensions namely innovations, risk taking and proactive (Fernando, 2005) motivational factor is a driving force of the degree of innovativeness and 
changes at public entrepreneurs worksites (Fernando, 2005). According to Fernando (2006) if there was an intention, then considerable opportunities could be found to introduce innovative and new ideas in their works. Hence, when appointing officers for administrative positions in State universities, despite the academicians' best results, special attentions has to be given to select academics who should have positive attitudes with achievement orientation.

This study also concludes that the support received from the working environment specially, from the academic staff of the faculty or department that enables managerial innovation. Hence, the availability of supportive academic staff is a must for managerial innovations in the public sector. As per Stone (1981) when innovative managers have been appointed and developed, they could able to develop innovative and participatory subordinates. By providing necessary supervision and guidance, getting involved them in decision making specially when designing new concepts and programs and also conducting training programs related to these works, the subordinates' supports could be obtained.

For improving innovative culture in the university, administrators should find various supports from outside the university such as support of the mass media and private sector. Bienkowska et al. (2010 cited in Potts \&Kastelle, 2010, p. 125) has conducted a study on public-private innovations and elaborated important lessons on how public sector innovation programmes can connect to private sector innovation programmes. When concerning external supports, Bogaards (1997 cited in Fernando, 2005, P.8) acknowledges two bases of support for entrepreneurs; political and public, that is, a favourable political climate and the support of the public. Thus, political support means not only the support of the government, but also of interest groups and the community that may lead them to act in new ways to do their jobs (Bogaards, 1997 cited in Fernando, 2005, P.8.).

Fernando (2006) has also highlighted citizen participation as external factors that affect for the public sector managers to be innovative. The external organizational supports are obtainable through conducting awareness programmes and seminars related to the activities of the degree programs, conducting research conferences with the supports of the external 
parties and requesting the relevant technical, financial and others supports from the external parties.Thus, efforts have to be taken to get external support that may lead to increased motivation for creative and innovative ideas of the administrators when managing the academic programs.

Skills of human resources in this study concerns the non-academic staff involved in the respective academic programmes, departments or faculties. Lau (2010) investigated the relationships between the levels of empowerment and perceived organizational support for innovations and organizational trust among non-academic professional employees within a public comprehensive university in a Midwestern State (USA) and found that organizational support for innovation perceived higher levels of empowerment of non-academic staff. Fernando (2006) also found that usually innovations happen with the employees who think of ways of doing their work more easily. Thus, the skills of non-academic staff require the successful implementation of innovative ideas.

As the non-academic support is an integral part of the university administration. When there is a supportive culture there is a tendency to have administrative innovations. Therefore, the experienced, capable, and committed workforce is mandatory. When recruiting non academics to the universities, unnecessary political interference should be avoided and there is a need to recruit a suitable workforce with supportive orientation to an innovative culture.

\section{References}

Arnaboldi, M., Azzone, G., \& Palermo, T. (2010). Managerial innovations in central government: Not wrong, but hard to explain. International Journal of Public Sector Management, 23(1), 78-93.

Awamleh, N. A. H. K. (1994). Managerial innovation in the civil service in Jordan. Journal of Management Development, 13(9), 52-62.

Borins, S. (2001). Encouraging innovation in the public sector. Journal of Intellectual Capital, 2(3).

Central Bank of Sri Lanka. (2009). Annual report.

Dewett, T., Whittier, N. C., \& Williams, S. D. (2007). Internal diffusion: The conceptualizing innovation implementation, Competitive Review: An International Business Journal, 17(1\&2). 
Drucker, P. F. (1994). Innovation and entrepreneurship. Oxford: Butterworth- Heinemann.

Fernando, R. L. S. (2004). Determinants of public entrepreneurship in the Sri Lankan administrative service. Amity Business Review, 2.

Fernando, R. L. S. (2005). Entrepreneurship in delivery of service in public sector. Network of Asia-Pacific Schools and Institutes of Public Administration and Governance (NAPSIPAG) Annual Conference, Beijing.

Fernando, R. L. S. (2006). Managerial innovation in delivery service in public sector organizations in Sri Lanka.In M. Salahuddin \& S. Aminuzzaman (Eds.), Governance and Development, (pp.221237).Dhaka: Shrabon Printing Press.

Georgellis, Y., Joyce, P., \& Woods, A. (2000). Entrepreneurial action, innovation and business performance: The small independent business. Journal of Small Business and Enterprise Development, 7(1), 7-17.

Goedhuys, M. (2007).The impact of innovation activities on productivity and firm growth. Maastricht: United Nations University.

Koch, P., \& Hauknes, J. (2005).Public Report (No.20).Retrieved from http/step. No/public/reports/d20-innovation.pdf on 5/13/2009.

Lau, W. K. J. (2010). Empowerment of non-academic personnel in higher education: Exploring associations with perceived organizational support for innovation and organizational trust. (Doctoral thesis, University of Iowa).Retrieved from

http://ir.uiowa.edu/cgi/viewcontent.cgi?article $=2028 \&$ context=etd

Leavy, B. (2010). A system for innovating business models for breakaway growth. Strategy and Leadership, 38(6), 5-15.

Liyanage, I.M. (2014).Education system of Sri Lanka: Strength and weakness. Chapter 7. 116-140.

Retrieved from

http://www.ide.go.jp/Japanese/Publish/Download/Report/2013/pdf/C 02_ch7.pdf.

Lopez, A. (2009). Organizational innovation and productivity growth: assessing. Summer Conference, Frederiksberg: Copenhagen Business School.

Lyonnais, D., \& Houle-Rutherford, D. (1996).Public Sector Innovation Journal. Retrieved from http://www.innovation.cc/discussionpapers/inovgove.htm on 14th June 2010.

Mansury, M. A., \& Love, J. H. (2008). Innovation, productivity and growth in US business services: A firm-level analysis. Technovation, 28(1-2), 52-62. 
Mohamed, M. A. K. (2002). Assessing determinants of departmental innovation: An exploratory multi-level approach.Personnel Review, $31(5)$.

Retrieved from http://www.emeraldinsight.com.insight/ViewContentservlert on $06 / 08 / 2010$.

Mohr, L. B. (1969). Determinants of innovation in organizations.The American Political Science Review, 63.

Mole, K., \& Worrall, L. (2001). Innovation, business performance and regional competitiveness in the West Midlands: Evidence from the West Midlands business survey. European Business Review, 13(6), 353-364.

Potts, J., \&Kastelle, T. (2010). Public sector innovation research: What's next? Innovations, 12(02), 122-137.

Ranasinghe, S. (2010).Breaking the mindsets: Issues of learning and innovation in Sri Lankan organizations. Sri Lankan Journal of Management, 7(3\&4).

Samaranayake, G. (2013). The role of state universities in the knowledge hub in Sri Lanka (Convocation speech delivered at the convocation of the Eastern university of Sri Lanka on the 20th of April 2013). The Island, Retrieved from http://www.island.lk/index.php?page_cat=articledetails\&page $=$ article-details\&code_title $=77951$ on 28.01.2016.

Shukla, A. (2009). Getting into roots: What is innovation and why innovation is important. Retrieved from http://www.paggu.com

Stone, D. C. (1981). Innovative organizations require innovative managers. Public Administration Review, 41(5), 507-513.

Tharmaseelan, N. (2007). Tertiary education in Sri Lanka: Issues \&challenges. Bulgarian Journal of Science and Education Policy, l(1), 173-190.

Thompson, V. A. (1965). Bureaucracy and innovation. Administrative Science Quarterly, 10(1), 1-20.

Vigoda-Gadot, E., Shoham, A., Schwabsky, N., \& Ruvio, A. (2008). Public sector innovation for Europe: A multinational eight- country exploration of citizens' perspectives. Public Administration, 86(2).

Walker, R. M. (2006). Innovation and type of diffusion. Public Administration, 84(2).

Warnapala, W. (2007).A speech delivered by Minister of Higher Education at a conference of vice chancellors at the University of Grants Commission on 4th May 2007. Retrieved from http://www.ncas.ac.lk/index.php?option=com_content\&task=view\&i $\mathrm{d}=80 \&$ Itemid $=45$ on $28 / 01 / 2015$. 
Yin, R. K. (1977). Production efficiency versus bureaucratic self-interest: Two innovative processes. Policy Sciences, 8(4), 381-399. 